Biljana D. Đorić

University of Kragujevac

Faculty of Technical Sciences Čačak

Department of Education Science and

Technology

Marija D. Blagojević

Department of Information Technologies

Miloš Ž. Papić

Department of Entrepreneurship Management
УДК 371.25-057.875:343.72

https://doi.org/10.18485/uzdanica.2020.17.1.12

Оригинални научни рад

Примљен: 20. јануар 2020.

Прихваћен: 8. јун 2020.

\title{
CHEATING IN ACADEMIC CONTEXT - ASSOCIATIONS WITH STUDY AREA, STUDY YEAR AND COUNTRY ${ }^{1}$
}

Abstract: The paper presents research conducted in order to examine the differences in students' propensity to cheat on exams according to their area of study, year of study and country of study. One of specific goals was to determinate the most dominant reason for cheating. The sample included 210 students (of which 90 freshmen and 120 senior students) from two universities in Serbia (University of Kragujevac and University of Belgrade) $(\mathrm{N}=168)$ and University of Applied Sciences in Austria $(\mathrm{N}=42)$. The sample consisted of students whose studies were in the following scientific areas: electrical and computer engineering $(\mathrm{N}=64)$, management and business $(\mathrm{N}=56)$, production technology and organization $(\mathrm{N}=42)$ and biological sciences $(\mathrm{N}$ $=48$ ). Results indicate that, in general, students cheat relatively rarely. Cheating mostly occurs when students are helping their colleagues. On the other hand, cheating is least likely to happen with means of illicit materials. Specific results show that biology students use illicit resources less when compared with other groups of students; that production technology and organization students provide help to other students less than electrical and computer engineering students and management and business students and that Serbian students are more likely to provide help to others compared to Austrian students. However, there are limitations to these conclusions. First-year students have also been found to be less likely to cheat (use illicit resources and provide help to others) than older students.

Keywords: students, cheating, dishonesty, deceptive means, exam.

\section{INTRODUCTION}

The problem of cheating starts in elementary schools and lasts until graduation from university. At university level of education, authors usually use the term

${ }^{1}$ This study was supported by the Ministry of Education, Science and Technological Development of the Republic of Serbia, and these results are parts of the Grant No. 451-03-68/202014/200132 with University of Kragujevac - Faculty of Technical Sciences Čačak. 
academic dishonesty to describe any form of cheating. This is a "constantly growing problem for academic community" (Tonković, Turina, Loos 2006: 1). With development of technology this problem gets new dimensions.

There are many definitions for the term "exam cheating", but in general, the term is related to copying from other students during exams (Wilkinson 2009: 98). Webster's New World Dictionary (1984) defines cheating as "being dishonest or deceitful". Carpenter et al. (2013: 181) define cheating as "copying on exams, fabricating a bibliography and falsifying lab data". Dahiya (2015: 793) defines cheating as "an illicit change of a grade, the use of helping materials during a test without permission or representing someone else's work as one's own". Jordan (2001: 233) states that cheating includes "lying; copying from another's test or examination; interacting with other students during assessments and taking any unauthorized material into an examination venue". According to Diego (2017: 121), "cheating occurs when a student obtains or attempts to obtain some advantage or extra marks by any dishonest or deceptive means".

Dahiya (2015: 794) made a list of four forms of academic dishonesty: (1) deception (providing false information to teacher), (2) plagiarism (when student submits others' work as its own), (3) sabotage (when student cannot finish its work because of other student's prevention) and (4) fabrication (falsification of data).

There are many related studies regarding cheating and academic dishonesty at universities. However, they examine different aspects of the issue.

One of them involves the use of information technologies for cheating ie. innovative, sophisticated mechanisms for cheating (Keresztury, Cser 2013: 1516; Parks, Lowry, Wigand, Agarwal, Williams 2018: 308; Wang, Tong, Ling, Zhang, Hao, Li 2015: 1009; Faucher, Caves 2009: 37). Srikanth and Asmatulu (2014: 129) state that these techniques include "cell phones, camera phones, earphones, MP3 players, graphing calculators, iPads, texting devices, monitoring devices, multifunctional watches, etc". However students still use traditional methods in cheating process, like communication in class during the exam or using a piece of paper with some parts of learning materials. According to Josien and Broderick (2013: 95), most of the students use direct communication (whispering) to mutually share the answers.

Different professional orientation of students is also an interesting aspect of academic cheating (Park, Park, Jang 2013: 346; Passow, Mayhew, Finelli, Harding, Carpenter 2006: 643; Löfström 2015: 1). Park, Park and Jang (2013: 346) examined cheating among nursing students, while Passow et al. examined engineering students and their reasons to cheat. Arhin and Jones (2009: 712) analysed perceptions about academic dishonesty in four different fields (mass communication, criminal justice, nursing and social work). They discovered most academic dishonest behavior among nursing students. On the other hand, Marsden, Carroll and Neill (2005: 6) revealed that higher level of dishonesty is shown by male students of engineering. 
Social aspects of cheating were the subject of interest for many authors as well (Lucifora, Tonello 2015: 45; Griebeler 2017: 1; Topîrceanu 2017: 171). Lucifora and Tonello (2015: 45) examined students' social externalities in cheating in two different circumstances: during exam in classroom with teacher and in class with an external inspector. Griebeler (2017: 1) concludes that probability of cheating could be higher if students have closer friendship and poor performing in class. Topîrceanu (2017: 171) used social network analysis in order to rearrange seats during exam in a way that allows appropriate distance between students who have string friendship in real world.

Characteristics of academically dishonest students and perceptions of the utility of ethics which affect academic cheating were the aspects reviewed by Miller et al. (2007: 9) and Winrow (2016: 1), respectively. Miller et al. (2007: 9) examined demographic, academic, behavioral, and personality related characteristics of cheater. The study provided significant results: students with lower abilities have a higher chance to be included in activities of cheaters. Winrow (2016: 1) found positive relationship between perceptions of utility of ethics in workplace and the frequency of academic cheating. He concluded that "the higher the student ranked ethics as a quality sought by employers when selecting a new employee, the lower the level of academic misconduct reported by that student".

Franklyn-Stokes and Newstead (1995: 163) analysed the relationship of students' age and cheating. Their findings reveal that older students (over 25 years) cheat less compared to their younger colleagues.

Magnus et al. (2010: 129) and Waugh (1995: 76) discussed the problem of different attitudes and perceptions about cheating among students in different countries. Waugh reported that Australian students agreed that cheating could be discouraged by introducing the penalties for cheating, while German students think that these methods could not discourage cheating. Lupton et al. (2000: 234) noticed that "Polish students were more likely to believe that most students cheat on exams than their American colleagues".

Students have many different reasons for cheating. Wang et al. (2015: 1010) classified them in two categories: characteristics of environment (e.g. classroom) and various possible human dependent situations which can occur during the test. Dahiya (2015: 794) identified four reasons for cheating: peer pressure, home environment, school environment and education anxiety. Dodeen (2012: 46) recognized time pressure and desire for good grades as most common reasons for cheating. Yardley et al. (2009: 6) reported about reasons for cheating of their alumni. First was "lack of time" and second was "helping a friend". Some students cheat on exam to please their parents according to Moeck (2002: 479). Amigud and Lancaster (2019: 100) identified as many as 246 reasons for cheating. One of them was that students usually try to finish the work by themselves and then, under pressure, they lose ability to complete it so eventually they cheat. 
Academic cheating could obviously be analyzed in many ways, but in this paper authors addressed the problem from three points of view: (1) Professional orientation - field and area of study; (2) Maturity - year of study; (3) Social and cultural environment - country in which students study.

\section{METHODOLOGY}

The main goal of this research was to examine the differences in students' propensity to cheat on exams according to their area of study, year of study and country of study. In addition, one of specific goals was to determinate the most dominant reason for cheating.

A non-experimental method was applied in order to fulfill the stated goals. The sample included 210 students (90 freshmen and 120 senior students) from four study fields within two universities in Serbia $(\mathrm{N}=168)$ and one University in Austria ( $\mathrm{N}=42)$. Number of students based on their year of study, field (area) of study and country of study is provided in Table 1 .

Table 1. Structure of the research sample

\begin{tabular}{lllcc}
\hline Country & University & Scientific field (scientific area) & $\begin{array}{c}1^{\text {st }} \text { year } \\
\text { students }\end{array}$ & $\begin{array}{c}\text { Senior } \\
\text { students }\end{array}$ \\
\hline Serbia & $\begin{array}{l}\text { University of } \\
\text { Kragujevac }\end{array}$ & $\begin{array}{l}\text { Technical and Technological Sciences (Electrical } \\
\text { and Computer Engineering) } \\
\text { Social Sciences and Humanities (Management } \\
\text { and Business) }\end{array}$ & 28 & 36 \\
& University of & $\begin{array}{l}\text { Natural and Mathematical Sciences (Biological } \\
\text { Sciences) }\end{array}$ & 20 & 28 \\
Austria & $\begin{array}{l}\text { University of } \\
\text { Total }\end{array}$ & $\begin{array}{l}\text { Technical and Technological Sciences } \\
\text { (Production Technology and Organization) }\end{array}$ & 21 & 21 \\
\hline
\end{tabular}

Serbia and Austria were chosen because of significant differences between these two countries regarding their culture and economic development. Austria is a region of predominant German and Catholic culture (Luft 1992: 93) while Serbia is predominantly Slavic and Orthodox country. On the other hand, Serbia and Austria have similar high educational systems. Besides all formal compliances promoted by the Bologna declaration, these countries have the same scientific fields as well as the same areas within these fields. For the purposes of this research, four scientific areas within three different scientific fields were selected.

As for the year of study, authors have chosen to compare first year students (freshmen) with students from older years (seniors). Reason for this is obvious to everyone who works in high education - freshmen usually spend the whole year to 
get used the new environment, new system of learning, new relationships between them and professors, etc.

Bearing in mind the aforementioned facts, research questions defined for this study were:

- Q1: How often do students cheat and to what degree do they cheat on different aspects of cheating (seeking help from colleagues, providing help to colleagues, using illicit resources, attitudes about the course)?

- Q2: Are there differences in propensity of cheating on exams between students attending different areas of study?

- Q3: Are there differences in propensity of cheating on exams between students of first year and students of older years?

- Q4: Are there differences in propensity of cheating on exams between students who study in different countiries (Serbia and Austria)?

- Q5: How do students rank the reasons for cheating and which is the most dominant one?

Instrument which the authors used to obtain the data needed to answer defined research questions was a questionnaire (provided in Appendix) which consisted of two parts. First part contained 18 statements with five-point Likert rating scale $(1-$ almost never, to 5 - very frequently), while second part consisted of seven statements which students ranked from 1 to 7 by importance to them. It should be noted that the second part of the questionnaire was previously used by Papić et al. (2018: 385) along with four statements from the first part.

The survey was conducted during the summer semester of the school year 2017/2018. Students filled the questionnaire in paper form at the end of class. Seven students were excluded from the sample because they did not answer all the questions.

The Cronbach alpha for 18 statements was 0.83 , which indicates the satisfactory reliability of the questionnaire. The questionnaire was composed of four subscales:

1. Seeking (using) help from colleagues (statements 1, 2, 4, 5, 6, 12, 13 and 14 - Cronbach alpha was 0.75 );

2. Providing help to colleagues (statements 3, 7 and 11 - Cronbach alpha was 0.66 );

3. Using illicit resources (statements 8,9 and 10 - Cronbach alpha was 0.6);

4. Attitudes about the course (statements 15, 16, 17 and 18 - Cronbach alpha was 0.76).

The lower Cronbach alpha coefficients for two subscales could be influenced by a small number of items (Tavakol, Dennick 2011: 54), but could also mean that the subscales are not sufficiently reliable. 


\section{RESULTS AND DISCUSSION}

Results of the research are presented and discussed in accordance with the defined questions. Multivariate analysis of variance (MANOVA), t-test and descriptive statistic were used to analyze the results.

\subsection{DIFFERENCES IN PROPENSITY OF CHEATING BETWEEN DIFFERENT ASPECTS OF CHEATING}

Table 2 shows the descriptive indicators for all four study areas with mean scores for all four subscales.

Table 2. Descriptive indicators of assessment of frequency of cheating

\begin{tabular}{|c|c|c|c|c|}
\hline \multicolumn{5}{|l|}{ Descriptive Statistics } \\
\hline & Area & Mean & Std. Deviation & $\mathrm{N}$ \\
\hline \multirow[t]{5}{*}{ Seeking (using) help from colleagues } & EEC & 2.3496 & .58933 & 64 \\
\hline & MB & 2.3951 & .61088 & 56 \\
\hline & PTO & 2.4881 & .46918 & 42 \\
\hline & $\mathrm{B}$ & 2.4010 & .70047 & 48 \\
\hline & Total & 2.4012 & .59897 & 210 \\
\hline \multirow[t]{5}{*}{ Providing help to colleagues } & EEC & 3.9167 & .68236 & 64 \\
\hline & $\mathrm{MB}$ & 3.9048 & .86390 & 56 \\
\hline & PTO & 3.3889 & .72102 & 42 \\
\hline & $\mathrm{B}$ & 3.7847 & 1.01406 & 48 \\
\hline & Total & 3.7778 & .84298 & 210 \\
\hline \multirow[t]{5}{*}{ Using illicit resources } & EEC & 1.9010 & .70192 & 64 \\
\hline & MB & 1.9107 & .75073 & 56 \\
\hline & PTO & 1.6746 & .62681 & 42 \\
\hline & $\mathrm{B}$ & 1.2639 & .46105 & 48 \\
\hline & Total & 1.7127 & .69974 & 210 \\
\hline \multirow[t]{5}{*}{ Attitudes about the course } & EEC & 2.9219 & .90838 & 64 \\
\hline & MB & 2.7366 & 1.03619 & 56 \\
\hline & PTO & 2.9286 & .85055 & 42 \\
\hline & $\mathrm{B}$ & 2.7708 & 1.10828 & 48 \\
\hline & Total & 2.8393 & .97826 & 210 \\
\hline
\end{tabular}

ECE - electrical and computer engineering; MB - management and business;

PTO - production technology and organization; B - biological sciences

Data from Table 2 indicate that students in all areas cheat relatively rarely by any means. Students provide help to others more often than they seek it or use illicit resources. The reason for this may be that they do not have an impression of cheating since they are helping others. Good collegial and friendly relations 
may contribute to this false impression (Griebeler 2017). Franklyn-Stokes and Newstead (1995) showed that high percent of students allow copying and copy coursework with knowledge.

The second highest marked categories are attitudes about the course. Means for the category which included statements about influence of attitudes toward subject are not high. It means that they cheat relatively rarely based on their perception of importance of subject, sanctions, upfront rules about the exam and quality of the course. The least important category for cheating is using illicit resources.

In order to determine whether there are statistically significant differences in estimates for the four aspects of cheating, a paired t-test was conducted. The results are shown in Table 3.

Table 3. Differences between four categories of cheating

\begin{tabular}{|c|c|c|c|c|c|c|c|c|}
\hline Categories & & Mean & $\mathrm{t}$ & df & $\mathrm{p}$ & Lower & Upper & $\begin{array}{c}\text { Eta } \\
\text { Square }\end{array}$ \\
\hline \multirow{3}{*}{$\begin{array}{l}\text { Seeking (using) } \\
\text { help from } \\
\text { colleagues }\end{array}$} & $\begin{array}{l}\text { Providing help to } \\
\text { colleagues }\end{array}$ & -1.38 & -26.248 & 209 & .000 & -1.48 & -1.27 & .77 \\
\hline & Using illicit material & .69 & 13.095 & 209 & .000 & .58 & .79 & .45 \\
\hline & Attitudes about the course & -.44 & -6.778 & 209 & .000 & -.57 & -.31 & .18 \\
\hline \multirow{2}{*}{$\begin{array}{l}\text { Providing help to } \\
\text { colleagues }\end{array}$} & Using illicit resources & 2.07 & 30.824 & 209 & .000 & 1.93 & 2.19 & .82 \\
\hline & Attitudes about the course & .94 & 11.976 & 209 & .000 & .78 & 1.09 & .41 \\
\hline $\begin{array}{l}\text { Attitudes about } \\
\text { the course }\end{array}$ & Using illicit material & -1.14 & -16.131 & 209 & .000 & -1.26 & -.99 & .55 \\
\hline
\end{tabular}

Data presented in Table 3 show that there are statistically significant differences in mean values for all aspects of cheating $(p=.000)$. The major difference in mean values was obtained between the categories Providing help to colleagues and Using illicit resources, followed by difference between the categories Seeking (using) help from colleagues and Providing help to colleagues. The smallest difference in average values is between the categories Seeking (using) help from colleagues and Attitudes about the course. Eta square was over 0.14 for all compared categories, which is a large influence according to Cohen (Cohen 1988: 284).

Based on these findings, it can be concluded that different aspects of cheating are represented differently, which is why it would be useful to determine what influences those aspects. Social aspects of cheating (providing assistance) stand out in relation to the use of illicit means. Significant difference was also noted between the categories of providing assistance and seeking assistance. Namely, students prefer providing assistance rather than seeking it. 


\subsection{DIFFERENCES IN PROPENSITY OF CHEATING BETWEEN STUDENTS ATTENDING DIFFERENT AREAS OF STUDY}

One-factor multivariant analysis of variance (MANOVA) explored differences in more frequent exam cheating between students who attend studies in four different areas. Four dependent variables were used: seeking (using) help from colleagues, providing help to colleagues, using illicit resources and attitudes about the course. The independent variable was the study filed.

Preliminary analysis proved the assumption of normality, linearity, univariate and multivariate atypical points, homogeneity of the variance-covariance matrix and multicollinearity. Maximal Mahalanobis distance for all groups of data was 14.19 which is acceptable (18.47 is allowed for four depend variables) (Pallant 2009: 286).

Statistically significant difference was found between students who attend different studies when considering the combination of dependent variables, $\mathrm{F}(12.615)=5.18, \mathrm{p}=0.000$, Pillai's trace $=0.28$; partial eta squared $=0.092$.

When the results of the dependent variables were considered separately, the differences that reached statistical significance were the estimate of the frequency of use of illicit resources in the exam, F (3.206) $=11.060, p=0.000$, partial eta squared $=0.139$ (which is according to Cohen large effect) and frequency of giving help to other, $\mathrm{F}(3.206)=4.164, \mathrm{p}=0.007$, partial eta squared $=0.057$ which is according to Cohen medium effect (Cohen 1988: 284). The results of the post-hoc analysis showed which groups had differences (Table 4).

Data listed in Table 4 show differences between the group of students studying biological sciences and all other students for category of using illicit resources. It is shown that students who study biological sciences cheat less than management and business students (MD = -.647) and less than electrical and computer engineering students $(\mathrm{M}=-.637)$. The smallest mean difference, but still statistically significant, has been shown between biology students and production technology and organization students ( $\mathrm{MD}=-.411)$. Also, production technology and organization students provide help to others less than electrical and computer engineering students ( $\mathrm{MD}=-.528)$ and management and business students $(\mathrm{MD}=-.516)$. It should be noted that all biology students come from University of Belgrade, and all production technology and organization students come from University of Applied Sciences (Austria). These facts could produce confounding effects. For example, the differences that have been found between study fields could actually exist due to characteristics of of university or country. Because the study fields were not uniformly distributed by university or country (Table 1), these findings are very tentative and future research should parse out the impact of university vs. study field and country vs. study field. 
Đorić D. B. and al., Cheating in academic context...; УЗДАНИЦА; 2020, XVII/1; стр. 195-212

Table 4. Results of post-hoc analysis - differences among students of different areas

\begin{tabular}{|c|c|c|c|c|c|c|c|}
\hline \multirow[t]{2}{*}{ Dependent Variable } & \multirow[t]{2}{*}{ (I) Area } & \multirow[t]{2}{*}{ (J) Area } & \multirow{2}{*}{$\begin{array}{c}\text { Mean } \\
\text { Difference } \\
(\mathrm{I}-\mathrm{J})\end{array}$} & \multirow[t]{2}{*}{ Std. Error } & \multirow[t]{2}{*}{ Sig. ${ }^{b}$} & \multicolumn{2}{|c|}{$\begin{array}{l}99 \% \text { Confidence Interval } \\
\text { for Difference }\end{array}$} \\
\hline & & & & & & $\begin{array}{l}\text { Lower } \\
\text { Bound }\end{array}$ & $\begin{array}{l}\text { Upper } \\
\text { Bound }\end{array}$ \\
\hline \multirow{12}{*}{$\begin{array}{l}\text { Using illicit } \\
\text { resources }\end{array}$} & \multirow[t]{3}{*}{ EEC } & MB & -.0097 & .13328 & 1.000 & -.4387 & .4193 \\
\hline & & PTO & .2264 & .13059 & .412 & -.1960 & .6488 \\
\hline & & B & .6372 & .11012 & .000 & .2823 & .9920 \\
\hline & \multirow[t]{3}{*}{ MB } & EEC & .0097 & .13328 & 1.000 & -.4193 & .4387 \\
\hline & & PTO & .2361 & .13935 & .439 & -.2146 & .6868 \\
\hline & & B & .6468 & .12039 & .000 & .2572 & 1.0364 \\
\hline & \multirow[t]{3}{*}{ PTO } & EEC & -.2264 & .13059 & .412 & -.6488 & .1960 \\
\hline & & MB & -.2361 & .13935 & .439 & -.6868 & .2146 \\
\hline & & B & .4107 & .11740 & .005 & .0280 & .7935 \\
\hline & \multirow[t]{3}{*}{ B } & EEC & -.6372 & .11012 & .000 & -.9920 & -.2823 \\
\hline & & MB & -.6468 & .12039 & .000 & -1.0364 & -.2572 \\
\hline & & PTO & -.4107 & .11740 & .005 & -.7935 & -.0280 \\
\hline \multirow{12}{*}{$\begin{array}{l}\text { Providing help to } \\
\text { colleagues }\end{array}$} & \multirow[t]{3}{*}{ EEC } & MB & .0119 & .14353 & 1.000 & -.4511 & .4749 \\
\hline & & РTO & .5278 & .14019 & .002 & .0727 & .9828 \\
\hline & & B & .1319 & .16941 & .967 & -.4195 & .6834 \\
\hline & \multirow[t]{3}{*}{$\mathrm{MB}$} & EEC & -.0119 & .14353 & 1.000 & -.4749 & .4511 \\
\hline & & PTO & .5159 & .16033 & .011 & -.0027 & 1.0344 \\
\hline & & B & .1200 & .18641 & .987 & -.4832 & .7233 \\
\hline & \multirow[t]{3}{*}{ PTO } & EEC & -.5278 & .14019 & .002 & -.9828 & -.0727 \\
\hline & & MB & -.5159 & .16033 & .011 & -1.0344 & .0027 \\
\hline & & B & -.3958 & .18385 & .186 & -.9925 & .2009 \\
\hline & \multirow[t]{3}{*}{ B } & EEC & -.1319 & .16941 & .967 & -.6834 & .4195 \\
\hline & & MB & -.1200 & .18641 & .987 & -.7233 & .4832 \\
\hline & & PTO & .3958 & .18385 & .186 & -.2009 & .9925 \\
\hline
\end{tabular}

Because of the diversity of teaching content that students experience in different fields, it is possible that not all students are equally able to cheat in a similar way. Engineering students usually rationalize reason for cheating, such as "the teacher did not work well" or "the instructor assigned too much material" as it is stated in Carpenter et al. (2013: 192). Another study also found that engineering students cheat more than students in the fields of economy, science and journalism (Marsden, Carroll, Neill 2005: 6). Franklyn-Stokes and Newstead (1995) found differences in cheating behavior between students of two areas of science faculty. 


\subsection{DIFFERENCES IN PROPENSITY OF CHEATING ON EXAMS BETWEEN STUDENTS OF FIRST YEAR AND STUDENTS OF OLDER YEARS}

Differences in the estimation of frequency of cheating between freshmen and senior students are presented in Table 5.

Table 5. Descriptive indicators for assessing the frequency of cheating (freshmen and seniors)

\begin{tabular}{|c|c|c|c|c|}
\hline \multicolumn{5}{|l|}{ Descriptive Statistics } \\
\hline & Year & Mean & Std. Deviation & $\mathrm{N}$ \\
\hline \multirow{3}{*}{ Seeking (using) help from colleagues } & I & 2.4417 & .60202 & 90 \\
\hline & II, III, IV & 2.3708 & .59738 & 120 \\
\hline & Total & 2.4012 & .59897 & 210 \\
\hline \multirow{3}{*}{ Providing help to colleagues } & I & 3.6000 & .90663 & 90 \\
\hline & II, III, IV & 3.9111 & .76907 & 120 \\
\hline & Total & 3.7778 & .84298 & 210 \\
\hline \multirow{3}{*}{ Using illicit resources } & I & 1.4556 & .57940 & 90 \\
\hline & II, III, IV & 1.9056 & .72205 & 120 \\
\hline & Total & 1.7127 & .69974 & 210 \\
\hline \multirow{3}{*}{ Attitudes about the course } & $\mathrm{I}$ & 2.8444 & .99407 & 90 \\
\hline & II, III, IV & 2.8354 & .97041 & 120 \\
\hline & Total & 2.8393 & .97826 & 210 \\
\hline
\end{tabular}

One-factor multivariant analysis of variance (MANOVA) investigated differences in cheating between freshmen and senior students. Four dependent variables were used: seeking (using) help from colleagues, providing help to colleagues, using illicit resources and attitudes about the course. The independent variable was the year of study.

A statistically significant difference was found between students attending first year and older students when considering the combination of dependent variables, $\mathrm{F}(4.205)=11.39, \mathrm{p}=.000$, Pillai's trace $=.18$; partial eta squared $=.182$.

When the results of the dependent variables were considered separately, the differences that reached statistical significance were the estimates of the frequency of use of illicit resources in exam, $\mathrm{F}(1.208)=23.566, \mathrm{p}=0.000$, partial eta squared $=0.102$ which is according to Cohen large effect (Cohen 1988: 284), and giving help to other students, $\mathrm{F}(1.208)=7.213, \mathrm{p}=.008$, partial eta squared $=.034$, which is according to Cohen small effect (Cohen 1988: 284). Data from Table 4 show that first-year students estimate that they are less likely to cheat using illicit resources $(M=1.46)$ than older students $(M=1.91)$. Also, they provide help to others less $(\mathrm{M}=3.6)$ than older students $(\mathrm{M}=3.91)$.

These results suggest that students may become more daring and prone to cheat on exams over the course of studying. This is in line with results of other authors (Marsden, Carroll, Neill 2005: 6). This raises a number of research ques- 
tions, including: how students value their future profession, subjects and professors; what is it that encourages them to cheat; are they aware of the consequences of cheating on the exam, not only in terms of punishment but also problems in later professional work; how is their ethical consciousness developed; what are their attitudes towards the business and professional behavior, the method of employment; and most importantly - how much and why they are prone to cheat outside the academic setting.

Teachers can play an important role in order to reduce student cheating (Dahiya 2015: 796). One of possible methods is informing students at the beginning of school year about serious consequences for them. University policy and the manner of sanctioning can also influence students' decision to cheat. Teachers should point out to students the far-reaching consequences of cheating, not only during their studies, but also in their professional future work.

In order to more precisely determine the ways to prevent cheating in the academic context, it is necessary to first determine the motives and reasons for such behavior. If students claim to be cheating due to frequent tests and a real lack of time, then teachers should reschedule exam activities. On the other hand, it would be useful to examine both how teachers see cheating and how well versed they are in possible ways of cheating in an academic context.

\subsection{DIFFERENCES IN PROPENSITY OF CHEATING ON EXAMS BETWEEN STUDENTS IN DIFFERENT COUNTIRIES}

Estimation of frequency of cheating between students of different countries is presented in Table 6 .

Table 6. Descriptive indicators for assessing the frequency of cheating (Serbian and Austrian students)

\begin{tabular}{lllrr}
\hline Descriptive Statistics & & & & \\
& \multicolumn{1}{c}{ Year } & Mean & Std. Deviation & $\mathrm{N}$ \\
\hline Seeking (using) help from colleagues & Serbia & 2.3795 & .62655 & 168 \\
& Austria & 2.4881 & .46918 & 42 \\
& Total & 2.4012 & .59897 & 210 \\
\hline Providing help to colleagues & Serbia & 3.8750 & .84508 & 168 \\
& Austria & 3.3889 & .72102 & 42 \\
& Total & 3.7778 & .84298 & 210 \\
\hline Using illicit resources & Serbia & 1.7222 & .71823 & 168 \\
& Austria & 1.6746 & .62681 & 42 \\
& Total & 1.7127 & .69974 & 210 \\
\hline Attitudes about the course & Serbia & 2.8170 & 1.00875 & 168 \\
& Austria & 2.9286 & .85055 & 42 \\
& Total & 2.8393 & .97826 & 210 \\
\hline
\end{tabular}


One-factor multivariant analysis of variance (MANOVA) explored differences in more frequent exam cheating between students who attend studies in two countries (Serbia and Austria). Four dependent variables were used: seeking (using) help from colleagues, providing help to colleagues, using illicit resources and attitudes about the course. The independent variable was the country in which students study.

A statistically significant difference was found between Serbian and Austrian students when considering the combination of dependent variables, $F(4,205)=$ $5.76, \mathrm{p}=.000$, Pillai's trace $=.1$; partial eta squared $=.101$.

When the results of the dependent variables were considered separately, the only difference that reached statistical significance was the estimates of the frequency of providing help to others, $\mathrm{F}(1,208)=11.748, \mathrm{p}=.001$, partial eta squared $=.053$, which is near medium effect (Cohen 1988).

Serbian students provide help to others more often $(M=3.87)$ than Austrian students $(M=3.39)$. For other three categories there are no statistical differences. The reason for this could be in cultural and social differences between these two countries. Other authors discovered differences in perception toward cheating between American and Polish students (Lupton, Chapman, Weiss 2000). Magnus et al. (2010) emphasize different attitudes among students in different countries. Magnus concluded that there are cultural and value differences between United States and Russia regarding value of competition and attitude to the low. However, as it was already mentioned, all Austrian students in this research come from one study field (production technology and organization). Thus, noted differences attributed to their country of study may actually be something that is attributable to their study field. In this context, the focus of future research will be aimed on examining individual net contribution of various factors using multiple linear regression analysis.

\subsection{REASONS FOR CHEATING}

In order to determine the most dominant reasons for cheating in academic settings, the frequency analysis was conducted. Its results are presented in Table 7.

Data from Table 7 show that most students offered as the most important reason for cheating - the lack of second chance for improving results. Positive finding is that the students are not subject to a great degree to the external motives for success such as the influence of parents, teachers, colleagues, material gains, etc.

Papić et al. (2018: 386) also revealed that most of the students' high-ranked reasons related to the inability to improve the grade, and low-ranked reasons to the influence of professors and desire to be better than others. Wang et al. (2015: 1011) found that the most probable reason for cheating is little time for learning. Similarly, Park et al. (2013: 350) highlighted the following major reasons for cheat- 
ing: higher grade, lack of time, better job and lack of motivation. Other authors recognize time pressure (Dodeen 2012), losing ability to complete a task (Amigud, Lancaster 2019), helping a friend (Yardley et al. 2009), time pressure and increasing the grade (Franklyn-Stokes, Newstead 1995) as the main reasons for cheating.

Table 7. Results of ranking the reasons for cheating

\begin{tabular}{|c|c|c|c|c|c|c|c|}
\hline & \multicolumn{7}{|c|}{$\begin{array}{l}\text { Given estimates for importance of reasons (\%); N = } 209 \\
\text { (One student did not rank reasons in questionnaire) }\end{array}$} \\
\hline & 1 & 2 & 3 & 4 & 5 & 6 & 7 \\
\hline Pressure from parents to be a good student & 17.5 & 14.9 & 18.4 & 10.5 & 18.4 & 13.2 & 7.0 \\
\hline Pressure from professors & 12.3 & 17.5 & 10.5 & 18.4 & 20.2 & 16.7 & 4.4 \\
\hline Pressure of high stakes test (one chance only) & 10.5 & 1.8 & 4.4 & 8.8 & 3.5 & 14.0 & 57.0 \\
\hline Pressure to do better than colleagues & 15.8 & 18.4 & 22.8 & 16.7 & 8.8 & 13.2 & 4.4 \\
\hline $\begin{array}{l}\text { Threat of not being able to participate in extracurricular } \\
\text { activities }\end{array}$ & 17.5 & 14.0 & 18.4 & 16.7 & 13.2 & 13.2 & 7.0 \\
\hline $\begin{array}{l}\text { Threat of losing privileges like pocket money from } \\
\text { parents }\end{array}$ & 13.2 & 18.4 & 16.7 & 14.0 & 13.2 & 16.7 & 7.9 \\
\hline $\begin{array}{l}\text { Rewards offered for getting good grades like money } \\
\text { or material things }\end{array}$ & 13.2 & 14.9 & 8.8 & 14.9 & 22.8 & 13.2 & 12.3 \\
\hline
\end{tabular}

\section{CONCLUSION}

This research revealed the following:

- All groups of students estimate their preference for cheating as relatively low. Compared to other categories, students are most prone to provide help, followed by attitudes about the course, seeking help from colleagues and using illicit resources. This finding could be the reason for extending the research to investigate social characteristics of such students.

- Students from different scientific areas may differ in the use of illicit resources and providing help to others.

- Students of biological sciences may least frequently use illicit resources.

- Production technology and organization students may provide help to others less frequently than electrical and computer engineering students and management and business students.

- Younger students use illicit resources and help others less than older colleagues.

- Serbian students may help others more frequently than Austrian students.

- The most dominant reason for cheating is a lack of second chance for improving results. 
We should again point out the limitation of the study, namely the potential confounding effects of the study field, university and country. Therefore, further research should be undertaken with larger, more uniformly distributed sample of students in more study fields across more universities and countries.

The other implications for future research would be to examine the impact of socio-psychological factors that may influence the tendency to cheat; to examine attitudes about particular courses (subjects) and their impact on ethical academic behavior. It would also be useful to extend the research towards determining effects of perceived self-efficacy, personal characteristics and social relationships, correlations between cheating and academic achievement, and so on.

\section{REFERENCES}

Amigud, Lancaster (2019): Alexander Amigud, Thomas Lancaster, 246 reasons to cheat: An analysis of students' reasons for seeking to outsource academic work, Computers \& Education, 134, 98-107.

Arhin, Jones (2009): Afua Ottie Arhin, Karin Jones, A multidiscipline exploration of college students' perceptions of academic dishonesty: Are nursing students different from other college students?, Nurse Education Today, 29(7), 710-714.

Carpenter, Harding, Finelli, Montgomery, Passow (2013): Donald Carpenter, Trevor Harding, Cynthia Finelli, Susan Montgomery, Honor Passow, Engineering Students' Perceptions of and Attitudes Towards Cheating, The research journal for engineering education, 95(3), 181-194.

Cohen (1988): Jacob Cohen, Statistical Power Analysis for the Behavioral Sciences, New York: Routledge Academic.

Dahiya (2015): Sarita Dahiya, Academic cheating among students: pressure of parents and teachers, International Journal of Applied Research, 1(10), 793-797.

Diego (2017): Leo Andrew Diego, Friends with Benefits: Causes and Effects of Learners' Cheating Practices During Examination, IAFOR Journal of Education, 5(2), 121-138.

Dodeen (2012): Hamzeh Dodeen, Undergraduate Student Cheating in Exams, $D a$ mascus University Journal, 28(1), 37-55.

Faucher, Caves (2009): Dina Faucher, Sharon Caves, Academic dishonesty: Innovative cheating techniques and the detection and prevention of them, Teaching and Learning in Nursing, 4(2), 37-41.

Franklyn-Stokes, Newstead (1995): Arlene Franklyn-Stokes, Stephen Newstead, Undergraduate cheating: Who does what and why?, Studies in Higher Education, 20(2), 159-172.

Griebeler (2017): Marcelo de Griebeler, Friendship and in-class academic dishonesty, Economics Letters, 150, 1-3.

Jordan (2001): Augustus Jordan, College student cheating: the role of motivation, perceived norms, attitudes and knowledge of institutional policy, Ethics and Behaviour, 11(3), 233-247. 
Josien, Broderick (2013): Laurent Josien, Britton Broderick, Cheating in Higher Education: the Case of Multi-Methods Cheaters, Academy of Educational Leadership Journal, 17(3), 93-106.

Keresztury, Cser (2013): Balázs Keresztury, László Cser, New Cheating Methods in the Electronic Teaching Era, Procedia - Social and Behavioral Sciences, 93, 1516-1520.

Löfström (2015): Erika Löfström, Academic Integrity in Social Sciences, In: T. Bretag (Ed.), Handbook of Academic Integrity, Singapore: Springer, 1-13.

Lucifora, Tonello (2015): Claudio Lucifora, Marco Tonello, Cheating and social interactions. Evidence from a randomized experiment in a national evaluation program, Journal of Economic Behavior \& Organization, 115, 45-66.

Luft (1993): David Luft, Austria as a Region of German Culture: 1900-1938, 23, Austrian History Yearbook, 135-148.

Lupton, Chapman, Weiss (2000): Robert Lupton, Kenneth Chapman, John Weiss, International perspective: A cross-national exploration of business students' attitudes, perceptions, and tendencies toward academic dishonesty, Journal of Education for Business, 75(4), 231-235.

Magnus, Polterovich, Danilov, Savvateev (2002): Jan Magnus, Victor Polterovich, Dmitri Danilov, Alexei Savvateev, Tolerance of Cheating: An Analysis Across Countries, Research in Economic Education, 33(2), 125-135.

Marsden, Carroll, Neill (2005): Helen Marsden, Marie Carroll, James Neill, Who cheats at university? A self-report study of dishonest academic behaviours in a sample of Australian university students, Australian Journal of Psychology, 57(1), 1-10.

Miller, Murdock, Anderman, Poindexter (2007): Angela Miller, Tamera Murdock, Eric Anderman, Amy Poindexter, Who are All These Cheaters? Characteristics of Academically Dishonest Students, Psychology of Academic Cheating, Amsterdam: Elsevier, 9-32.

Moeck (2002): Pak Moeck, Academic dishonesty: Cheating among community college students, Community College Journal of Research and Practice, 26(6), 479-491.

Pallant (2007): Julie Palant, SPSS survival manual - A step by step guide to data analysis using SPSS for windows (3rd ed.), Maidenhead: Open University Press.

Papić, Blagojević, Hochrinner, Kraguljac (2018): Miloš Papić, Marija Blagojević, Hagen Hochrinner, Vladimir Kraguljac, Student Attitudes about Cheating in High Education, 7th International Scientific Conference Technics and Informatics in Education - TIE 2018, Faculty of Technical Scineces, Čačak, Serbia, 383-387.

Park, Park, Jang (2013): Eun-Jun Park, Seungmi Park, In-Sun Jang, Academic cheating among nursing students, Nurse Education Today, 33(4), 346-352.

Parks, Lowry, Wigand, Agarwal, Williams (2018): Rachida Parks, Paul Benjamin Lowry, Rolf Wigand, Nitin Agarwal, Therese Williams, Why students engage in cybercheating through a collective movement: A case of deviance and collusion, Computers \& Education, 125, 308-326.

Passow, Mayhew, Finelli, Harding, Carpenter (2006): Honor Passow, Matthew Mayhew, Cynthia Finelli, Trevor Harding, Donald Carpenter, Factors influencing engineering students' decisions to cheat by type of assessment, Research in Higher Education, 47(6), 643-684.

Schmelkin, Gilbert, Spencer, Pincus, Silva (2008): Liora Pedhazur Schmelkin, Kim Gilbert, Karin Spencer, Holly Pincus, Rebecca Silva, A multidimensional scaling of col- 
lege students' perceptions of academic dishonesty, The Journal of Higher Education, 79(5), 587-607.

Srikanth, Asmatulu (2014): Madhulika Srikanth, Ramazan Asmatulu, Modern Cheating Techniques, Their Adverse Effects on Engineering Education and Preventions, International Journal of Mechanical Engineering Education, 42, 129-140.

Tavakol, Dennick (2011): Mohsen Tavakol, Reg Dennick, Making sense of Cronbach's alpha, International journal of medical education, 2, 53-55.

Tonković, Turina, Loos (2006): Maša Tonković, Irina Turina, Daria Loos, Prepisivanje na ispitima: stavovi i ponašanje studenata, Neobjavljeni istraživački članak nagrađen rektorovom nagradom, Zagreb: Filozofski fakultet Sveučilišta u Zagrebu

Topîrceanu (2017): Alexandru Topîrceanu, Breaking up friendships in exams: A case study for minimizing student cheating in higher education using social network analysis, Computers \& Education, 115, 171-187.

Wang, Tong, Ling, Zhang, Hao, Li (2015): Jiamin Wang, Ye Tong, Mindan Ling, Anting Zhang, Liping Hao, Xingsen Li, Analysis on Test Cheating and its Solutions Based on Extenics and Information Technology, Procedia Computer Science, 55, 1009-1014.

Waugh, Godfrey, Evans, Craig (1995): Russell Waugh, John Godfrey, Ellis Evans, Delores Craig, Measuring students' perceptions about cheating in six countries, Australian Journal of Psychology, 47(2), 73-80. Books.

Webster's New World Dictionary (1984): $2^{\text {nd }}$ edition, New York, New York: Warner

Wilkinson (2009): Jenny Wilkinson, Staff and student perceptions of plagiarism and cheating, International Journal of Teaching and Learning in Higher Education, 20(2), 98-105.

Winrow (2016): Brian Winrow, Do perceptions of the utility of ethics affect academic cheating?, Journal of Accounting Education, 37, 1-12.

Yardley, Domenech Rodríguez, Bates, Nelson (2009): Jennifer Yardley, Melanie Domenech Rodríguez, Scott Bates, Johnathan Nelson, True Confessions?: Alumni's Retrospective Reports on Undergraduate Cheating Behaviors, Ethics \& Behavior, 19(1), 1-14.

\section{APPENDIX}

1. Consider each of the following situations. How often do you think you find yourself in such situations? Mark your answer in the table with an X.

\begin{tabular}{|c|c|c|c|c|c|}
\hline Situation & Never & Rare & $\begin{array}{l}\text { Some- } \\
\text { times }\end{array}$ & Often & $\begin{array}{l}\text { Very } \\
\text { often }\end{array}$ \\
\hline You didn't do your homework so you copy it from a colleague. & & & & & \\
\hline $\begin{array}{l}\text { You did the major part of your homework except for a couple of } \\
\text { problems so you copy them from a colleague. }\end{array}$ & & & & & \\
\hline $\begin{array}{l}\text { Your colleague didn't finish his/her homework so you let him/her } \\
\text { copy yours. }\end{array}$ & & & & & \\
\hline
\end{tabular}


Đorić D. B. and al., Cheating in academic context...; УЗДАНИЦА; 2020, XVII/1; стр. 195-212

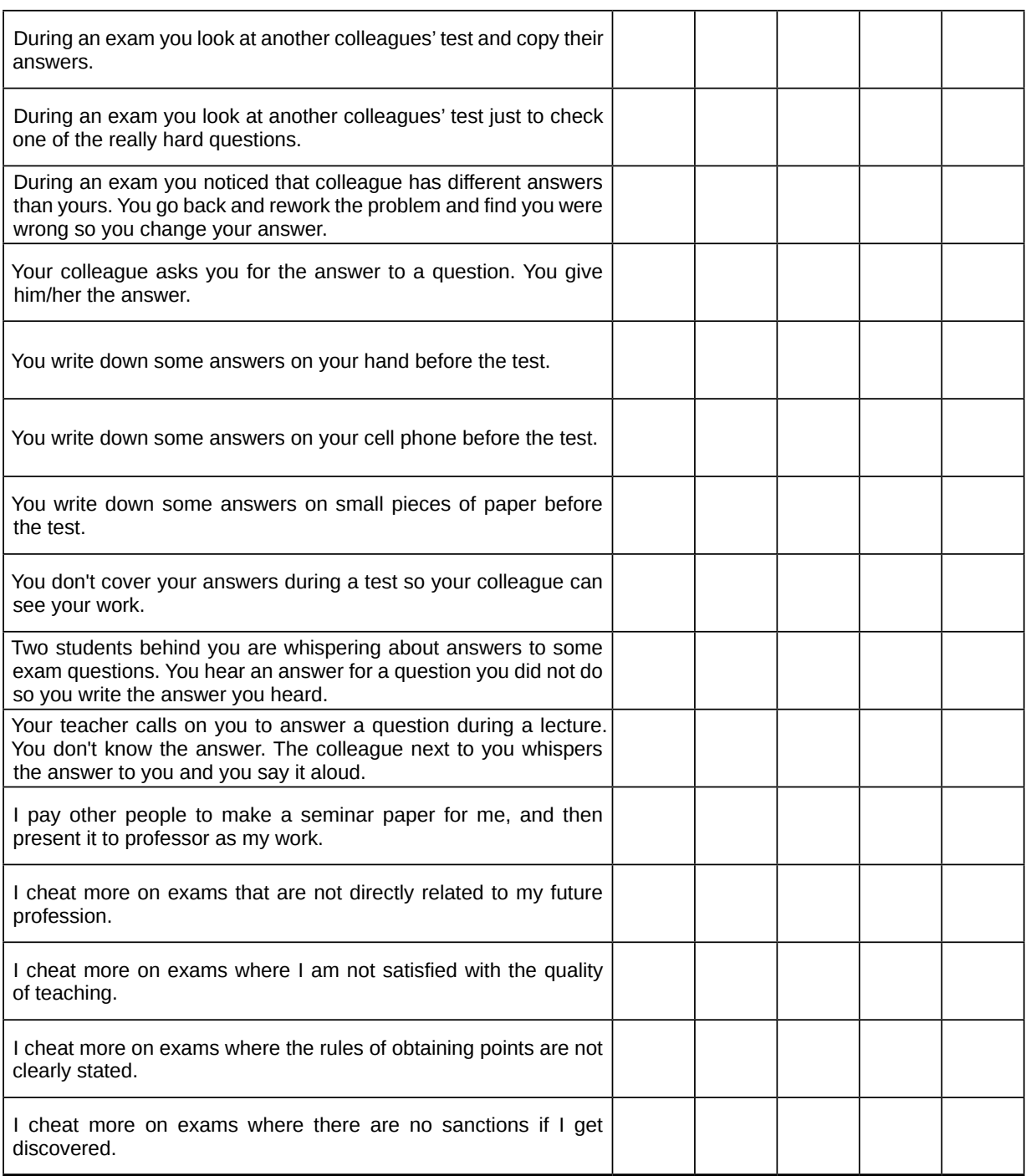

\section{Several reasons for cheating are listed below. Rank them from 1 (the least} reason to cheat) to 7 (the greatest reason to cheat).

Pressure from parents to be a good student.

Pressure from professors.

Pressure of high stakes test (one chance only).

Pressure to do better than colleagues.

Threat of not being able to participate in extracurricular activities.

Threat of losing privileges like pocket money from parents.

Rewards offered for getting good grades like money or material things. 


\section{Биљана Д. Ђорић}

Универзитет у Крагујевцу

Факултет техничких наука Чачак

Катедра за педагошко-техничке науке

Марија Д. Благојевић

Катедра за информационе технологије

Милош Ж. Папић

Катедра за предузетнички менаџмент

\section{НЕПОШТЕЊЕ У АКАДЕМСКОМ ОКРУЖЕЊУ - ПОВЕЗАНОСТ СА ОБЛАШЋУ СТУДИЈА, ГОДИНОМ СТУДИЈА И ЗЕМЉОМ}

Резиме: У раду је приказано истраживање које је имало за циљ испитивање постојања разлика у склоности студената да варају на испитима у зависности од њихове области студија, године студија и места, односно земље где студирају. Један од специфичних циљева било је утврђивање доминантног разлога варања. Узорак је чинило 210 студената (од чега 90 бруцоша и 120 старијих студената) са два универзитета у Србији (Универзитет у Крагујевцу и Универзитет у Београду) (Н = 168) и Универзитета примењених наука у Аустрији $(\mathrm{H}=42)$. Учесници истраживања су студенти чије су студије из следећих научних области: електротехничко и рачунарско инжењерство ( $\mathrm{H}=64)$, менаџмент и пословање $(\mathrm{H}=56)$, производна технологија и организација $(\mathrm{H}=42)$ и биолошке науке $(\mathrm{H}=48)$. Резултати показују да студенти у академском контексту варају релативно ретко. Помагање колегама у испитним ситуацијама се показало као најизраженији облик варања. Са друге стране, студенти исказују да је употреба недозвољених средстава најмање заступљен облик варања. Детаљнији резултати показују да студенти биологије мање користе недозвољена средства у поређењу са другим групама студената; да студенти у области производне технологије и организације пружају помоћ другим студентима мање него студенти електротехнике и рачунарске технике и студенти менаџмента и бизниса; да српски студенти радије пружају помоћ другима у поређењу са аустријским студентима. Такође је утврђено да студенти прве године мање варају (мање користе недозвољена средства и пружају помоћ другима) од старијих.

Кључне речи: студенти, варање, непоштење, недозвољена средства, испит. 